\title{
DEVELOPMENT OF REGIONAL LABOUR MARKETS IN CONDITIONS OF DECENTRALIZATION
}

\author{
Lidiia TKACHENKO ${ }^{1}$ \\ PhD in Economics, Senior Researcher \\ M.V. Ptukha Institute of Demography and Social Research \\ of the National Academy of Sciences of Ukraine, Ukraine
}

DOI: https://doi.org/10.36004/nier.es.2020.2-10

JEL Classification: H70, J21, J68, R58

CZU: 331.5

\section{ABSTRACT}

The decentralization reform in Ukraine began in 2014 and is aimed at implementing the provisions of the European Charter of Local Self-Government, which provides for the redistribution of powers, resources and responsibilities on the basis of subsidiarity. Currently, local governments are endowed with powers and instruments of influence on enterprises located on their territory, but employment and labour market policies remains the prerogative of the central government. For a comparative analysis of the development of regional labour markets in the context of decentralization, labour force survey indicators are more appropriate, since they reflect the actual policy results from the perspective of households. For the 2015-2019 period in most regions of Ukraine, there was an increase in the level of employment and a decrease in the level of unemployment; at the same time, the gender gap in employment has increased in 16 of 25 regions; the sectoral structure of employment continues to stagnate. Some regions have significantly increased the coverage of public works, but this may indicate not the activity of territorial communities, but the lack of stable employment opportunities. Local selfgovernment bodies should play a key role in the formation and implementation of local employment and the labour market policies, their interaction with the state employment service requiring a corresponding transformation.

Keywords: labour market, regional development, local government, labour market policy, employment, unemployment, public works.

Reforma descentralizării din Ucraina a început în 2014 și are drept scop punerea în aplicare a prevederilor Cartei europene a autonomiei locale, care prevede redistribuirea competențelor, resurselor și responsabilitătilor pe baza subsidiarității. În prezent, guvernele locale sunt dotate cu puteri și instrumente de influență asupra întreprinderilor situate pe teritoriul lor, însă politicile de ocupare a forței de muncă și de piață a muncii rămân a fi o prerogativă a guvernului central. Pentru o analiză comparativă a dezvoltării piețelor muncii regionale în contextul descentralizării, indicatorii anchetei privind forța de muncă sunt mai adecvați, întrucât reflectă rezultatele actuale ale politicii din perspectiva gospodăriilor. Pentru perioada 2015-2019 în majoritatea regiunilor din Ucraina, a existat o creștere a nivelului de ocupare și o scădere a nivelului de șomaj; în același timp, diferența de gen în ocuparea forței de muncă a crescut în 16 din 25 de regiuni; structura sectorială a ocupării forței de muncă continuă să stagneze. În unele regiuni a crescut semnificativ încadrarea în lucrărilor publice, dar acest lucru indică mai degrabă activitatea comunităților teritoriale și lipsa unor oportunități de angajare stabile. Organismele locale de auto-guvernare ar trebui să joace un rol cheie în formarea și implementarea politicilor de ocupare a forței de muncă locale și a pieței forței de muncă, interacțiunea lor cu serviciul de ocupare a forței de muncă de stat necesitând o transformare semnificativă.

Cuvinte cheie: piața muncii, dezvoltare regională, administrația locală, politica pieței muncii, ocuparea forței de muncă, șomaj, lucrări publice. 
Реформа децентрализации в Украине началась в 2014 г. и направлена на имплементацию положений Европейской хартии местного самоуправления, которая предусматривает перераспределение полномочий, ресурсов и ответственности по принципу субсидиарности. Сейчас органы местного самоуправления уже наделены полномочиями и инструментами воздействия на предприятия, расположенные на их территории, но политика занятости и рынка труда остается прерогативой центральных органов власти. Для сравнительного анализа развития региональных рынков труда в условиях децентрализации более приемлемы показатели обследования рабочей силы, поскольку они отражают фактические результаты политики с позиции домохозяйств. За период 2015-2019 г2. в большинстве регионов Украины наблюдались рост уровня занятости и снижение уровня безработицы; в то же время в 16 из 25 регионов увеличился гендерный разрыв по уровню занятости; секторальная структура занятости продолжает стагнировать. Некоторые регионы значительно нарастили охват общественными работами, однако это может свидетельствовать не об активности территориальных единиц, а об отсутствии возможностей стабильного трудоустройства. Органы местного самоуправления должны играть ключевую роль в формировании и реализации локальной политики занятости и рынка труда, соответствующей трансформации требует их взаимодействие с государственной службой занятости.

Ключевые слова: рынок труда, региональное развитие, местное самоуправление, политика рынка труда, занятость, безработица, общественные работы.

\section{INTRODUCTION}

Decentralization is one of the key European integration reforms, launched in 2014 after the Association Agreement between Ukraine and the EU was signed. The reform is aimed at implementing the provisions of the European Charter of Local Self-Government and involves the transfer of a significant part of powers, resources and responsibility from central executive authorities to local self-government bodies that are in close proximity to the inhabitants of a territory. The redistribution of functions based on the principle of subsidiarity should provide residents with mechanisms and tools to influence local authorities and participate in decision-making. At the basic level, the institution of local self-government is that of united territorial communities ("hromady"), which are then combined into larger ones (hereinafter referred to as "hromady"). In 2014-2019 the formation and unification of the hromady proceeded on a voluntary basis, beginning with 2020 - according to long-term plans approved by the government.

One way or the other, decentralization, encompasses all spheres of activity and politics, changing the balance of power and priorities in markets and in society. The labour market is at the intersection of economic, demographic and social factors; therefore, the impact of decentralization requires analysis and improvement of regional employment and the labour market policies.

\section{LITERATURE REVIEW}

The experience of the hromada formation and activity is the focus of research by Ukrainian scientists and analysts. The attention of specialists in the field of labour economics and social economics is focused, first of all, on identifying new risks for the development of regional labour markets associated with decentralization. Such risks are most often called by the following factors (Benovska, 2019; Libanova, 2017; Romanyuk, 2019):

* the formation and unification of hromady is often formal in nature, without initiative and without a vision on new opportunities for local economic and social development;

* the behaviour of hromady is dominated by a consumerist approach, they are much more focused on receiving subsidies and subventions from higher-level budgets than on increasing economic activity on their territory;

* socio-economic disproportions are aggravated not only between regions but also within regions and districts; in particular, the concentration of economic activity in large cities is accelerating, while, at the same time there is a decline and desolation in small towns and villages; 
* the structural imbalance between supply and demand in local labour markets is growing, as a result of which unemployment increasingly exists in parallel with a shortage of personnel;

* the intensity of all types of labour migrations is increasing, starting with daily commuting and ending with long foreign ones; migrant workers travel is becoming a routine employment model;

* enterprises and individuals - entrepreneurs are increasingly choosing a place of registration based on the favourable conditions of local taxation, as a result of which the asymmetry between the fiscal and social aspects of the policy is growing;

* in the formation of policy, a clear "top-down" administrative vertical line is preserved, which determines a formal-declarative approach to the development of local development programs, measures for their implementation and monitoring of performance.

A survey of territorial hromady of four regions of the Carpathian area (Kravciv \& Instytut Rehional'nych Doslidžen', 2013), conducted in November 2018, showed that only $11 \%$ of hromady developed a program or action plan in employment. Some of them used the old employment programs, which were adopted even before the formation of the hromada without considering the new conditions. Even those hromady that developed their own employment program or plan did not consider the real data on the available labour potential. Among surveyed hromady, 2/3 did not have data on the age composition of the population, $1 / 3$ did not have information on the number of officially employed persons, $1 / 5$ did not know the number of locally registered individualsentrepreneurs. Most often, the activity of hromady on labour market issues was limited to a rather formal interaction with the local state employment centre ( $72 \%$ of the surveyed communities), $56 \%$ of communities taking part in the organization of public works. At the same time, almost all communities noted that limited opportunities for official employment on their territory constitute a problem for community development.

An important area of research is also the improvement of tools for measuring and assessing the dynamics of regional labour markets. Most often the following indicators are taken for comparative analysis: the employment rate, the unemployment rate, the rates of accepting and quitting of regular staff at enterprises, the scale of underemployment and informal employment, employment in harmful conditions and industrial injuries, the size of the average monthly wage of regular staff of enterprises and the declared salary in vacancies, performance indicators of the state employment service, including the number and structure of vacancies, the number of registered unemployed per vacancy (Bilyk \& Filipchuk, 2019; Шаульська \& Кримова, f.a.). The quarterly monitoring of regional socio-economic development (Ministry of communities and territories development of Ukraine 2020) contains 60 indicators in 12 areas, including the "labour market efficiency" block of four indicators: the unemployment rate according to the ILO methodology, the level of employment, the real wage index and the amount of wage arrears as a percentage of the wages fund.

A review of research shows that in Ukraine, in the context of decentralization, employment is viewed primarily as a component of the financial solvency of the local budget and the investment attractiveness of the territory, whereas issues of employment and unemployment are viewed as part of the state employment service activity. The social role of employment and the role of communities in employment policy are greatly underestimated.

The EU's regional policy aims at cohesion and harmonize development, and it is on this basis that it allows to combine job creation, competitive business, economic growth, sustainable development and improving the quality of life for people from all regions, cities and rural areas. Cohesion policy involves supporting local development initiatives and empowering local governments to manage funds (EU Budget, 2018). Thanks to this approach, employment and labour market policies is strongly represented at all management levels.

In countries with a high level of local decentralization (Poland, Belgium, Denmark, the Netherlands, Spain), the public employment service is part of regional self-government bodies and does not belong to the governmental executive vertical. This makes it possible to bring the labour market policy as close as possible to local conditions and needs, to establish specific local tasks and target groups. The disadvantage of fully decentralizing public employment services is represented 
by the difficulty to obtain integrated information on the provision of consulting services and active labour market policy measures across the country as a whole(European Commission. Directorate General for Employment, Social Affairs and Inclusion. \& ICON INSTITUT., 2016).

In countries where the public employment service is an autonomous public institution (France, Austria, Germany, Greece, Finland), there is also a tendency towards the decentralization of activities at local level. For example, in Germany, the 2003 reform at the local level created public employment agencies (that serve applicants with an unemployment duration of less than one year) and public job centres (that serve long-term unemployed), which closely interact with municipalities. This decentralization of functions and management allowed for a personalized, customer-centric approach, which reduced the average duration of unemployment and increased customer satisfaction for both job-seekers and employers (Finn et al., f.a.).

In countries where the public employment service is a centralized structure subordinate to the ministry (Ireland, UK) or government (Hungary, Sweden), there is also a tendency to deepen cooperation with local authorities. For example, the UK initiated the expansion of the standard service package with additional services (jobcentre plus), which facilitate a quick return to work thanks to the established local funds and tools. Cooperation also takes the form of joining the efforts of the public employment service with local social services to develop joint programs and deliver services tailored to the local situation and needs.

\section{DATA AND METHODS}

The situation on the labour market depends on the intersection of many factors, therefore, it is not possible to separately measure exclusively the impact of decentralization. Based on the objectives of the analysis, preference is given to indicators that characterize the social role of employment and, at least at the legislative level, provide for the significant participation and responsibility of local governments for employment and labour market policies.

The current national legislation refers to the powers of local self-government bodies as general administrative measures (preparation of programs for socio-economic development, etc.) (Verkhovna Rada of Ukraine 1997). Although local governments are endowed with powers and instruments of influence on enterprises located on their territory, comprehensive regional policy, employment and labour market policies remain the prerogative of the state and central executive authorities. Regional development strategies, territorial and local employment programs are fully subordinated to the main directions and principles of state policy, local state administrations are responsible for their development and implementation (Verkhovna Rada of Ukraine 2012 and 2015). Local self-government bodies in these processes have rather a coordinating and supportive role, being mentioned last in the list of entities responsible for implementation.

The only labour market policy measure where local governments play a significant role are public works, which by definition are a type of socially useful paid work in the interests of a territorial community. The practical involvement of local governments in organizing public works was facilitated by the establishment, in 2013, of the principle of parity of their funding from local budgets and funds from the Fund of Compulsory State Social Insurance against of unemployment (Cabinet of Ministers of Ukraine 2013). This prompted the territorial employment centres, which are strictly subordinate to the central vertical of power, to establish a more effective interaction with local authorities. In the crisis conditions of 2015, the requirement for parity funding was cancelled, since the lack of funds from local budgets called into question the conduct of public works, but, at least, the tradition of complicity was established.

Taking into account the existing distribution of powers, the data of the state employment service and other administrative data rather characterize the activities of the central executive authorities in the implementation of national policy. An exception here is the information on public works, the organization and financing of which are carried out with the active participation of local governments.

For a comparative analysis of the development of regional labour markets, data from labour force surveys are much more informative, since they reflect not indicators of activity, but the actual results of socio-economic policy in a given region, and this information is obtained from households, that is, directly from participants on the labour market. The capabilities of this source also have limitations. First, the 
survey methodology is clearly regulated and assumes a fairly standard set of statistical indicators. Secondly, when analysing in a regional context, the problem of data reliability arises. In particular, data on the unemployment rate in almost all regions have an error estimate of more than $10 \%$, which limits their use for quantitative analysis (State Statistics Service of Ukraine 2020).

Some researchers offer integral indices that allow synthesizing the content of a set of indicators and ranking regions by the value of the index and sub-indices (Bobukh \& Shchehel, 2019). However, for operational monitoring and management decisions, one still needs to focus on the initial values of the indicators, and there should not be many of these indicators. Considering existing sources of regular and reliable data, developments of national researchers and foreign experience (Eurostat, 2019) of socio-economic analysis of regional development, this work uses indicators such as those from table 1.

\section{List of indicators for a comparative analysis of the regional labour markets development in the context of decentralization}

\begin{tabular}{|l|l|l|}
\hline $\begin{array}{l}\text { Indicator name, measurement } \\
\text { unit }\end{array}$ & \multicolumn{1}{|c|}{ Definition or formula for calculating an indicator } & Data source \\
\hline Employment rate,\% & $\begin{array}{l}\text { Share of employed persons in total population aged 15- } \\
70\end{array}$ & $\begin{array}{l}\text { Labour force } \\
\text { research }\end{array}$ \\
\hline Unemployment rate, \% & $\begin{array}{l}\text { Share of unemployed persons in labour force aged 15- } \\
70\end{array}$ & $\begin{array}{l}\text { Labour force } \\
\text { research }\end{array}$ \\
\hline $\begin{array}{l}\text { Employment gender gap, } \\
\text { percentage points }\end{array}$ & $\begin{array}{l}\text { Difference between employment rates of women and } \\
\text { men }\end{array}$ & $\begin{array}{l}\text { Labour force } \\
\text { research }\end{array}$ \\
\hline $\begin{array}{l}\text { Sectoral employment structure } \\
\text { on National Classifier for Economic Activities KVED- } \\
\text { 2010 (analogue of NACE Rev.2) }\end{array}$ & $\begin{array}{l}\text { Labour force } \\
\text { research }\end{array}$ \\
\hline $\begin{array}{l}\text { Coverage of unemployed with } \\
\text { public works, \% }\end{array}$ & $\begin{array}{l}\text { Share of registered unemployed persons who were } \\
\text { involved in public works during the year }\end{array}$ & $\begin{array}{l}\text { State } \\
\text { employment } \\
\text { centre }\end{array}$ \\
\hline
\end{tabular}

Source: Own compilation.

The base year for comparison is 2015, when the implementation of decentralization began. The last reporting year for which a complete set of statistical indicators is available is 2019. In addition, in 2019, the first stage of decentralization was completed, in which territorial communities were formed and united on a voluntary basis. The dynamics of regional indicators and interregional differentiation for 2015-2019 allow you to assess the scale and consistency of changes at the stage of hromada formation.

\section{RESEARCH RESULTS AND DISCUSSIONS}

Employment rate and unemployment rate characterize the implementation of the labour supply, reflecting the regional potential for economic growth and the availability of the labour market. Employment opportunities and a choice of jobs are the key to the social well-being of the region's residents. On the contrary, a high unemployment rate can be an indicator of depressed areas.

In 2015-2019 in the regions of Ukraine, there was a heterogeneous dynamic of the levels of employment and unemployment, which may be, among other things, a consequence of the decentralization process. In most regions, there was an increase in employment, most significantly in the Khmelnytskiy, Luhansk, Sumy, Chernivtsi (more than +4 percentage points in each region) and Zhytomyr ( +3 percentage points) regions. At the same time, employment decreased in the Volyn (-2.2 percentage points), Dnipropetrovsk (-1.4), Zakarpattya (-0.8) regions (Fig. 1) 


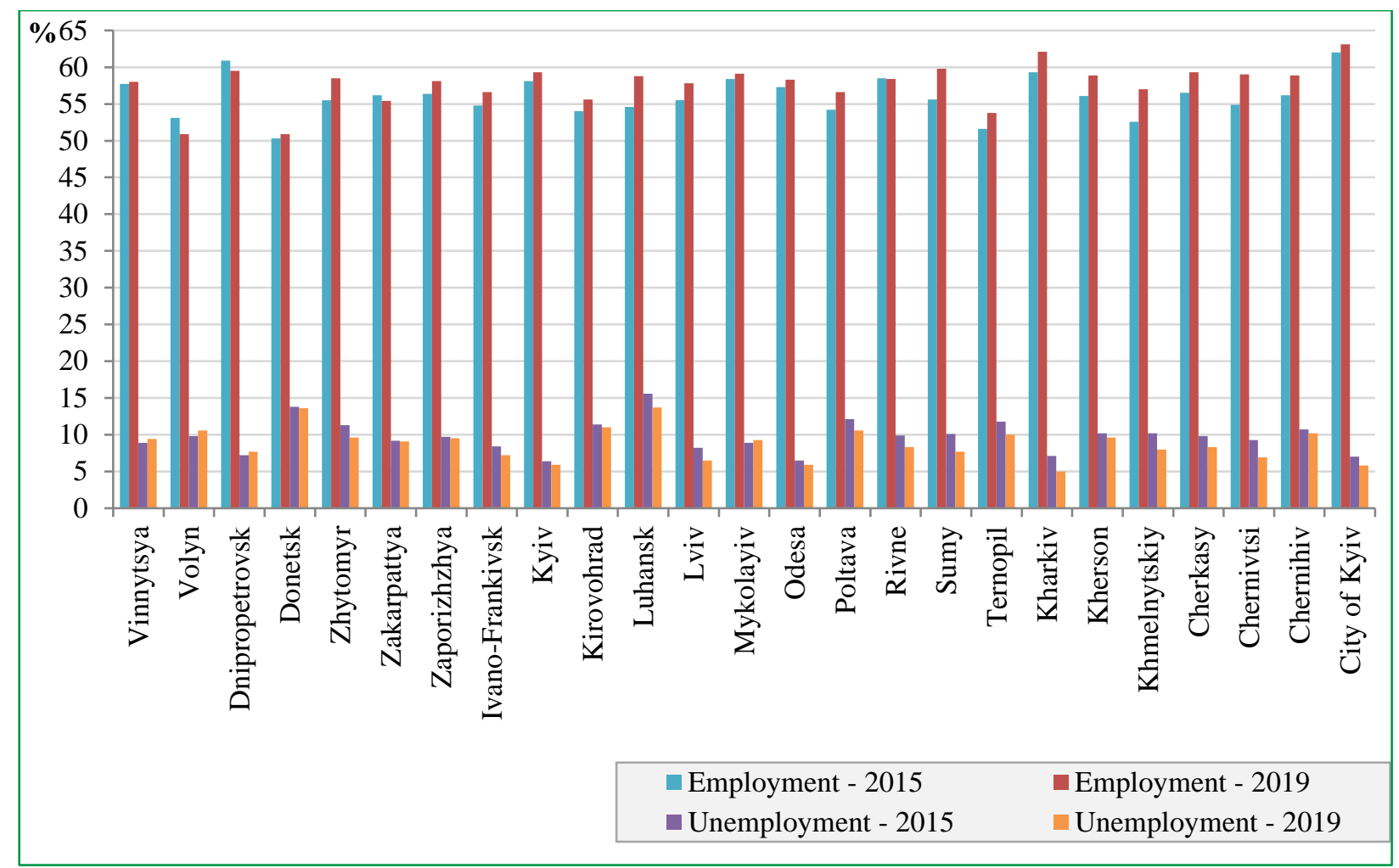

Figure 1. Employment and unemployment rates of population aged 15-70 by regions of Ukraine in 2015 and $2019, \%$

Source: Based on data from State Statistics Service of Ukraine 2020.

The unemployment rate grew, although insignificantly, in four regions - Volyn, Vinnytsya, Dnipropetrovsk and Mykolayiv. Moreover, in the Volyn and Dnipropetrovsk regions, the increase in unemployment occurred against the background of a decrease in employment. The greatest success in reducing the unemployment rate was achieved by the Sumy, Chernivtsi, Khmelnytskiy, Kharkiv regions (a decrease of more than 2 percentage points). It should be noted that Zhytomyr, Khmelnytskiy, Volyn, Dnipropetrovsk regions were leaders in the rating of regions in terms of the hromada formation rate (Моніторинг процесу децентралізаціï, f.a.), but this was reflected in the levels of employment and unemployment in very different ways.

In general, there is a logical pattern that the most significant decrease in the unemployment rate occurred in regions where there was a significant increase in the employment rate, while in regions with a higher level of employment, there is a lower unemployment rate.

Employment gender gap characterizes the situation with the equality of opportunities for women and men in the labour market. In virtually all countries of the world, the employment rate for men is higher than the one for women, as women bear a greater burden of maternal and family responsibilities. Therefore, when analysing this indicator, the main attention is paid to the direction of the trend (with the right policy, the gender gap should be reduced), as well as interregional comparison.

For 2015-2019 in 16 out of 25 regions of Ukraine, the gender gap in terms of employment increased (Fig. 2). The largest growth occurred in the Zakarpattya region (twice), the Mykolayiv and Luhansk regions (by half in each), Ivano-Frankivsk and Chernivtsi regions (by a quarter in each). As a result, in 2019, the Zakarpattya, Ivano-Frankivsk and Chernivtsi regions became "leaders" in terms of the size of the gender gap (almost 20 percentage points). The largest reduction in the gender gap in terms of employment took place in Rivne, Lviv, Vinnytsya, Kharkiv regions. 


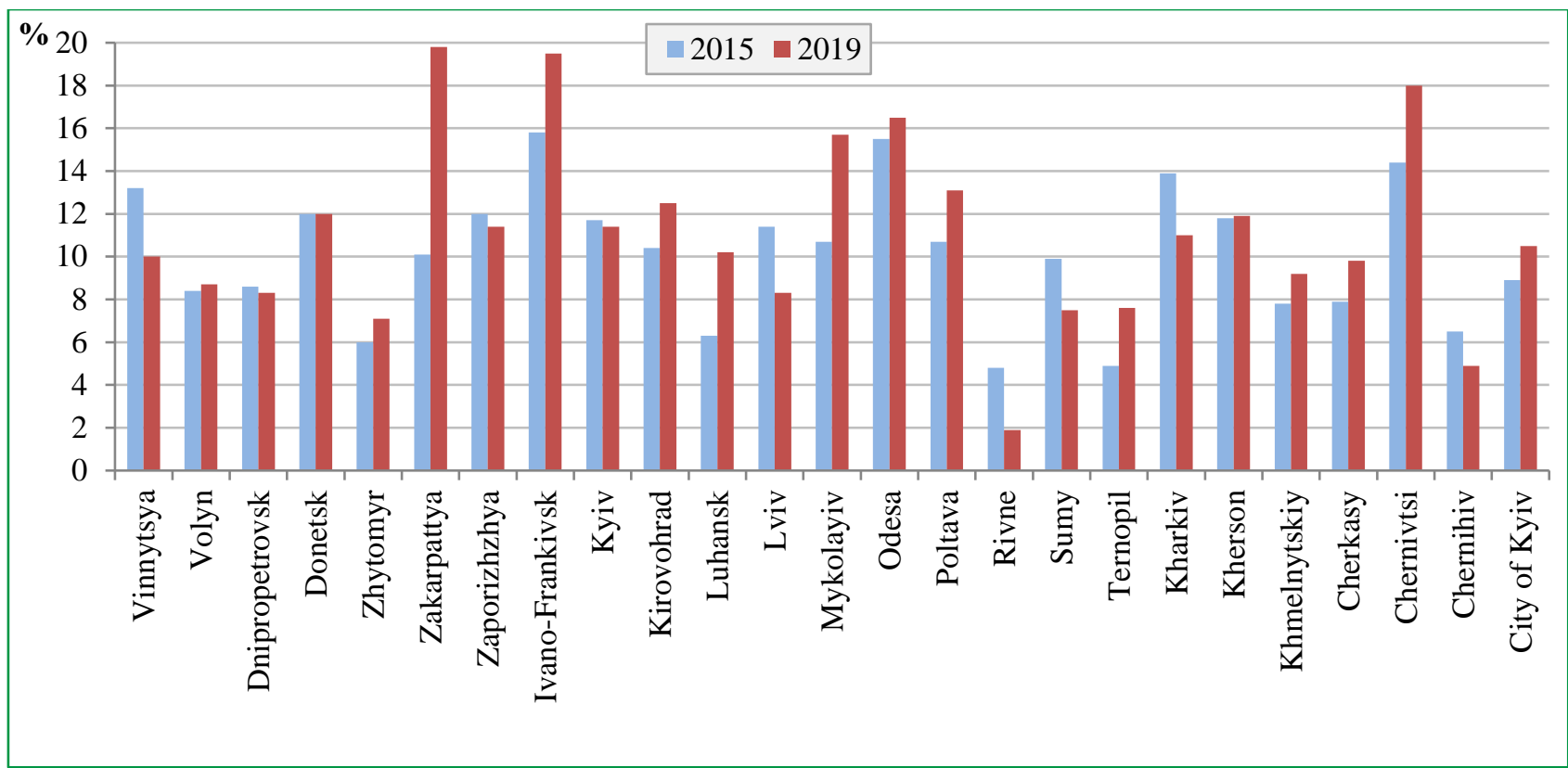

Figure 2. Gender gap in the employment rate of the population aged 15-70 by regions of Ukraine in 2015 and $2019, \%$

Source: Based on State Statistics Service of Ukraine 2020.

Interregional differentiation of the gender gap in terms of employment may be associated not only with the lack of jobs for women or the specifics of the sectoral structure of employment (spread of informal employment, labour migration, etc.), but also with the (in) accessibility of early childhood development infrastructure.

Sectorial employment structure characterizes the level of productivity and conditions of employment, for example, the opportunity to have a stable job with official registration, decent wages and a social package.

The industry sector provides predominantly stable, qualified, formal wage employment with wages significantly higher than the national average. Disadvantages of employment in this sector usually include tight working hours and risks of harmful working conditions. In Ukraine, industrial centres located mainly in the eastern regions - Dnipropetrovsk, Donetsk, Zaporizhzhya, Kharkiv, Luhansk, as well as Kiev and Poltava regions have formed historically. The share of industrial employment in these regions is over 15\%. The smallest specific weight (less than 10\%) is occupied by the industrial sector in the structure of employment in the Odesa, Kherson, Ternopil regions and the city of Kiev (table 2).

The business services sector includes three types of economic activities: information and telecommunications (section J), professional, scientific and technical activities (section M), activities in the field of administrative and support services (section N according to NACE-2010). This sector is highly innovative, capable of providing high quality employment with motivation to learn (High-Level Group on Business Services 2014). However, in Ukraine, hired labour in this sector is often disguised as selfemployment in the status of individuals - entrepreneurs, or is carried out in atypical conditions (freelancing, etc.). As a consequence, employment flexibility translates into weak social protection. In terms of the structural share of employment in the business services sector, the city of Kyiv is by far the leader (over 20\%), which is explained by the status of the capital. Among the regions, a significant percentage of employment in the business services sector comes to Kyiv, Kharkiv, Dnipropetrovsk regions (7-9\%). This sector is least represented in the Zakarpattya and Chernivtsi regions (less than 3\%). 
Table 2

Share of employment in selected sectors of economy by regions of Ukraine in 2015 and 2019,\%

\begin{tabular}{|c|c|c|c|c|c|c|}
\hline Sector $\rightarrow$ & \multirow{2}{*}{\multicolumn{2}{|c|}{$\frac{\text { Industry }}{\mathrm{B}+\mathrm{C}+\mathrm{D}+\mathrm{E}}$}} & \multirow{2}{*}{\multicolumn{2}{|c|}{$\frac{\text { Business Services }}{\mathrm{J}+\mathrm{M}+\mathrm{N}}$}} & \multirow{2}{*}{\multicolumn{2}{|c|}{$\frac{\text { Public services }}{0+P+Q+R}$}} \\
\hline Sections of NACE $1 \rightarrow$ & & & & & & \\
\hline Regions & 2015 & 2019 & 2015 & 2019 & 2015 & 2019 \\
\hline Vinnytsya & 11 & 11 & 4 & 3 & 23 & 21 \\
\hline Volyn & 13 & 14 & 3 & 3 & 26 & 25 \\
\hline Dnipropetrovsk & 25 & 24 & 6 & 7 & 19 & 18 \\
\hline Donetsk & 33 & 26 & 5 & 5 & 19 & 19 \\
\hline Zhytomyr & 14 & 15 & 5 & 4 & 26 & 23 \\
\hline Zakarpattya & 11 & 11 & 2 & 2 & 21 & 20 \\
\hline Zaporizhzhya & 22 & 22 & 5 & 5 & 21 & 18 \\
\hline Ivano-Frankivsk & 12 & 12 & 4 & 3 & 22 & 20 \\
\hline Kyiv & 18 & 18 & 9 & 9 & 26 & 23 \\
\hline Kirovohrad & 13 & 13 & 3 & 4 & 24 & 22 \\
\hline Luhansk & 31 & 19 & 4 & 5 & 19 & 18 \\
\hline Lviv & 14 & 15 & 6 & 6 & 25 & 22 \\
\hline Mykolayiv & 13 & 13 & 3 & 3 & 21 & 20 \\
\hline Odesa & 8 & 8 & 6 & 6 & 23 & 21 \\
\hline Poltava & 18 & 17 & 4 & 4 & 23 & 20 \\
\hline Rivne & 13 & 13 & 4 & 3 & 23 & 21 \\
\hline Sumy & 16 & 14 & 4 & 4 & 23 & 21 \\
\hline Ternopil & 9 & 9 & 3 & 3 & 26 & 22 \\
\hline Kharkiv & 19 & 19 & 7 & 7 & 21 & 19 \\
\hline Kherson & 9 & 9 & 4 & 3 & 24 & 21 \\
\hline Khmelnytskiy & 12 & 12 & 3 & 3 & 25 & 22 \\
\hline Cherkasy & 14 & 14 & 4 & 4 & 21 & 19 \\
\hline Chernivtsi & 10 & 11 & 3 & 3 & 22 & 19 \\
\hline Chernihiv & 12 & 12 & 4 & 4 & 25 & 24 \\
\hline City of Kyiv & 8 & 8 & 20 & 21 & 23 & 22 \\
\hline
\end{tabular}

Source: Based on State Statistics Service of Ukraine 2020.

The public services sector includes economic activities dominated by budgetary and non-profit institutions that provide services such as: public administration and defence; compulsory social insurance (section 0), education (section P), health and social assistance (section Q), arts, sports, entertainment and recreation (section R according to NACE-2010). These services are provided to the population directly at the local level and play a key role in human development opportunities. As a field of employment, this sector usually provides a stable job with formalization and a full package of social protection. At the same time, the level of wages in the public sector of the social sphere remains almost the lowest of all types of economic activity. Since government or sectoral policies play an important role in the public services sector, regional differentiation in the share of employment in this sector is less pronounced. The regions with a predominance of the population of large cities have the lowest share, where it is possible to use the public infrastructure network more efficiently due to the density of settlement.

In 2015-2019 structural shifts in the sectors of industry and business services are almost imperceptible, while the share of employment in the public services sector has decreased in all

\footnotetext{
${ }^{1}$ NACE - Classifier of Economic Activities
} 
regions by 1-3 percentage points, which is a consequence of government reforms to "optimize" the infrastructure network.

Coverage of unemployed with public works characterizes the level of cooperation between local governments and the state employment service. It should be remembered that public works are a temporary form of employment and do not solve the problem of finding a suitable job and stable employment. This is why most EU countries do not practice public works at all, with the exception of Greece, Ireland, Italy and new member states (Anna Manoudi 2014).

For the period 2015-2019 the level of coverage of registered unemployed with public works decreased in five regions (Sumy, Cherkasy, Lviv, Poltava, Ternopil), in three it remained unchanged (Vinnytsya, Rivne and Khmelnytskiy), in other regions, there was an increase (Fig. 3). The most rapid growth was observed in Donetsk (from 13\% in 2015 to 54\% in 2019) and Luhansk (from 14\% to $31 \%$ ) regions, which have a high unemployment rate. This means that the interpretation of this indicator is rather contradictory. On the one hand, the high coverage of public works testifies to the active position of local self-government bodies, on the other hand, to the unfavourable situation in the labour market and the lack of reliable employment opportunities.

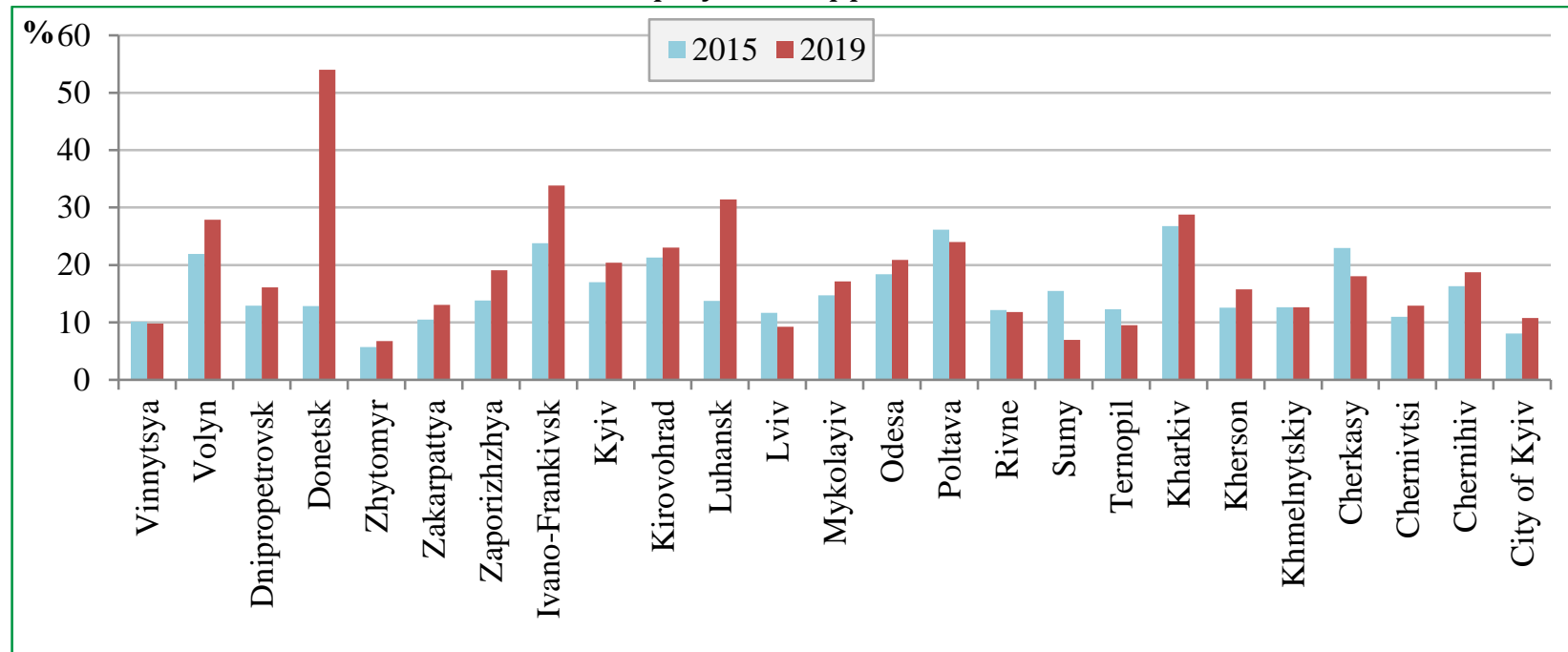

Figure 3. Coverage of registered unemployed persons with public services by regions of Ukraine in 2015 and 2019 , as \% of total registered unemployed

Source: Based on the website of the "State Employment Center of Ukraine". URL: https://www.dcz.gov.ua/storinka/vidkryti-dani

Summarizing the analysis of the indicators, it should be noted that with the start of the decentralization reform, not so much time has passed for its advantages to become obvious in such a delicate and multifactorial substance as the labour market. Nevertheless, it is safe to say that several regions have been able to significantly improve their performance. And these are not only regions that previously demonstrated success (Kharkiv, Kyiv regions), but also regions that were considered economically depressed for a long time - Sumy, Cherkasy, Zhytomyr regions.

\section{CONCLUSIONS}

Study results make it possible to substantiate the following new directions of regional development policy:

* to expand the powers of local self-government bodies in the formation and implementation of employment and labour market policies, in particular, transfer the local employment policy to the list of their own powers and delegate powers to participate in the implementation of the national employment and labour market policy;

* to adapt the organizational and managerial model of the state employment service to the conditions of decentralization, to provide for more flexibility and freedom in the formation of local target programs and instruments of active labour market policy, for example, for vocational training 
and integration of vulnerable groups of the population with the involvement of resources of territorial communities;

* to supplement the directions of local employment policy with new target groups. Since depopulation takes place in Ukraine and the working-age population is rapidly declining, pension reform measures, such as raising the retirement age, limiting early retirement, and linking the age of granting a pension to the criteria for the length of service, become a source of maintaining the labour force. This means that local employment and labour market policies need to be oriented not only towards young people, as is the case now, but also to older people.

Further research is needed in the direction of improving the system of development indicators and developing an institutional model for regulating regional labour markets in the context of decentralization.

\section{REFERENCES}

1. Benovska, L. (2019). Strengthening the differentiation of the development of territorial communities as a risk of decentralization reform. Regional Economy, 1(91), 24-30. https://doi.org/10.36818/1562-0905-2019-1-3

2. Bilyk, R., \& Filipchuk, N. (2019). Problems of economic security and regions' competitiveness in conditions of decentralization. Regional Economy, 4(94), 53-63. https://doi.org/10.36818/15620905-2019-4-4

3. Bobukh, I., \& Shchehel, S. (2019). Inclusive development of Ukrainian regions: Assessment, rankings and prospects. Regional Economy, 4(94), 36-52. https://doi.org/10.36818/1562-0905-2019-4-3

4. EU budget: Regional Development and Cohesion Policy beyond 2020. (2018, mai 29). [Text]. European Commission - European Commission. https://ec.europa.eu/commission/presscorner/detail/en/IP_18_3885

5. European Commission. Directorate General for Employment, Social Affairs and Inclusion. \& ICON INSTITUT. (2016). Assessment report on PES capacity: 2016. Publications Office. https://data.europa.eu/doi/10.2767/861018

6. Eurostat, D. E. (2019). Adjusted gross disposable income of households per capita (2010-2019). http://appsso.eurostat.ec.europa.eu/nui/show.do?dataset=tec00113\&lang=en

7. Finn, D., Peromingo, M., \& Mwasikakata, O. M. (f.a.). Key developments, role and organization of Public Employment Services. 140.

8. Kravciv, V. S., \& Instytut Rehional'nych Doslidžen' (Ed.). (2013). Karpats'kyj rehion: Aktual'ni problemy ta perspektyvy rozvytku: monohrafija u 8 tomach. NAN Ukrä̈ny, Instytut Rehional'nych Doslidžen'.

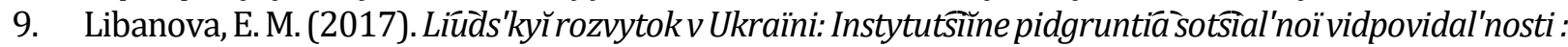
Kolektyvna monohrafiiâ.

10. Romanyuk, S. A. (2019). Regional Development in Ukraine: Past, Today. Future? Demography and social economy, 1(3), 113-132. https://doi.org/10.15407/dse2019.03.113

11. Моніторинг процесу децентралізації. (f.a.). Preluat în 24 iunie 2021, din https://decentralization.gov.ua/mainmonitoring

12. Шаульська, Л. В., \& Кримова, М. О. (f.а.). СТАН РИНКУ ПРАЦІ В КОНТЕКСТІ СТРАТЕГІЇ РОЗВИТКУ ЛЮДСЬКОГО КАПІТАЛУ $P$. Preluat în 24 iunie 2021, din http://webcache.googleusercontent.com/search?q=cache:SUpJEVUAlAUJ:www.irbisnbuv.gov.ua/cgibin/irbis_nbuv/cgiirbis_64.exe\%3FC21COM\%3D2\%26I21DBN\%3DUJRN\%26P21DBN\%3DUJRN\% 26IMAGE_FILE_DOWNLOAD\%3D1\%26Image_file_name\%3DPDF/rpzn_2018_2_5.pdf+\&cd=2\&hl=r o\&ct=clnk\&gl=md

\section{ARTICLE HISTORY}

Received 01 april 2020

Accepted 20 may 2021 